Available online on 15.05.2020 at http://jddtonline.info
Open Access to Pharmacentical and Medical Research
undestricted non-commercial use, provided the original work is properly cited

Open $\odot$ Access

Research Article

\title{
Antioxidant chlorophyll purification from maize leaves by liquid-to-liquid extraction method
}

\section{Dang Xuan Cuong}

Nha Trang Institute of Technology Application and Research, Vietnam Academy of Science and Technology, Nha Trang 650000, Khanh Hoa, Vietnam

\begin{abstract}
Chlorophyll is the blood of plant possesses a medical-value for treating support of disease in human, and the paper focused on the purification of antioxidant chlorophyll extracting from maize leaves in Vietnam. Chlorophyll was extracted with $96 \%$ ethanol and segmented by different solvents, for example, $\mathrm{n}$-hexane, $96 \%$ ethanol, and ethyl acetate, respectively. Ethanol fraction was running via the chromatography column of silica gel for collecting antioxidant purified chlorophyll. All fractions were analysed chlorophyll content, antioxidant activities (total antioxidant activity, reducing power activity, and DPPH free radical scavenging activity) and run the thin layer chromatography for deter mining the chlorophyll purification degree and the $\mathrm{R}_{\mathrm{f}}$. The results showed that the purification of antioxidant chlorophyll from maize leaves was by using the liquid-liquid segment and the column run, for example, in turn, ethanol, $\mathrm{n}$-hexane, ethanol, and the silica gel chromatography. The highest value of chlorophyll content, total antioxidant activity, reducing power activity, and DPPH free radical scavenging activity was $0.563 \pm 0.003 \mu \mathrm{g}$ chl equivalent $/ \mathrm{ml}, 1.392 \pm 0.018 \mathrm{mg}$ ascorbic acid equivalent $/ \mathrm{ml}, 3.396 \pm 0,024 \mathrm{mg} \mathrm{FeSO} / \mathrm{ml}$, and $76.34 \pm 0.81$ (\%), respectively, as the $\mathrm{n}$ hexane/ethanol ratio of $1 / 1(\mathrm{v} / \mathrm{v})$. After the chromatography run, chlorophyll content, total antioxidant activity, reducing power activity, and DPPH free radical scavenging activity corresponded to $0.217 \pm 0.002 \mu \mathrm{g}$ chl equivalent $/ \mathrm{ml}, 0.628 \pm 0.013 \mathrm{mg}$ ascorbic acid equivalent $/ \mathrm{ml}$, $1.928 \pm 0.019 \mathrm{mg} \mathrm{FeSO}_{4} / \mathrm{ml}$, and $77.19 \pm 0.58(\%)$, respectively.
\end{abstract}

Keywords: antioxidant, chlorophyll, maize, purification, liquid-to-liquid

Article Info: Received 09 March 2020; Review Completed 22 April 2020; Accepted 02 May 2020; Available online 15 May 2020

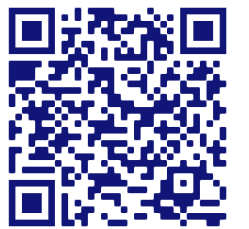

\section{Cite this article as:}

Cuong DX, Antioxidant chlorophyll purification from maize leaves by liquid-to-liquid extraction method, Journal of Drug Delivery and Therapeutics. 2020; 10(3):152-158 http://dx.doi.org/10.22270/jddt.v10i3.4104

\section{*Address for Correspondence:}

Technology, Nha Trang 650000, Khanh Hoa, Vietnam

\section{INTRODUCTION}

Chlorophyll is a green pigment commonly found in plants consisting of chlorophylls a, b, c, d and f. Chlorophylls compose of a porphyrin ring with a central magnesium ion $(\mathrm{Mg} 2+)$ existing in a long hydrophobic chain, described by Richard who got the nobel prize in chemistry 1915. Richard showed the chlorophyll structure and the relationship between chlorophyll and the hemoglobin in human blood 1,2 . In 1930, Hans Fischer who got the nobel prize in chemistry 1930 showed the regeneration ability of red blood cell from chlorophyll ${ }^{2}$. In nature, chlorophyll $\mathrm{a}$ and $\mathrm{b}$ are commonly found and composed of $-\mathrm{CH} 3$ and - $\mathrm{CHO}$, respectively. Chlorophyll $\mathrm{a}$ and $\mathrm{b}$ exhibits blue-green and yellow-green colour, respectively 3. Chlorophyll and their salts (chlorophyllin) are the useful components of foods pharmaceuticals, and cosmetics 4 . They possess different bioactive diverse, for example, antioxidant 5, cancer presentation ${ }^{6}$. In medicine, chlorophyll is a factor for dyeing the pills and water pills. Chlorophyll is useful for detoxing, healing skin wounds tumours prevention, the body deodorizing, haemoglobin increase, acne treatment, antibacterial, oral health improvement, mouth deodorant, intestinal system improvement, immune system stimulation, and acidophilic bacterial development. Therapeutic properties of chlorophyll also compose of immune system stimulation, anaemia combat, cancer-preventing, using in cancer therapy, intestines cleaning, anti-moulds, blood pressure normalization, the blood purification, toxins movement, anti-inflammatory, cell regeneration, and energize supply 7,8 .

Maize is a medicine plant and a food crop commonly grown in Vietnam and numerous areas in the world. The corn was used in food, excipients. Silk, husk, cob, leaves, and roots of maize was used in traditional medicine in Vietnam. Nowadays, silk, husk, cob, leaves, and roots of maize byproducts could use for extracting polyphenol (lignin, solubility polyphenol), animal feed production or fertilizer, except for leaves could use for collecting chlorophyll. 
Therefore, the study focused on chlorophyll purification from maize leaves, their antioxidant activities evaluation, and the correlation between chlorophyll content and antioxidant activities.

\section{MATERIALS AND METHODS}

\subsection{Materials}

Maize leaves collected on $75^{\text {th }}$ growth days of maize that were harvested corn, cleaned, dried, and crushed for further studies.

\subsection{Extract preparation}

Crushed maize was soaked in $96 \%$ ethanol at $\mathrm{pH} 8$ (adjusted by $\mathrm{Na} 2 \mathrm{CO} 3)$ with the ethanol-to-material ratio of $40 / 1(\mathrm{v} / \mathrm{w})$ for 60 minutes and filtered through the paper Whatman No 4 for collecting the supernatant. The extraction processing had ultrasonic assistance with Degas power at a frequency of $37 \mathrm{kHz}$. The extract vacuum concentration was continuously at the temperature of $50^{\circ} \mathrm{C}$ with the pressure of $100 \mathrm{mbar}$ until $20 \pm 1^{\circ}$ Brix and stored at $14^{\circ} \mathrm{C}$ under the dark condition for further studies.

The concentrated ethanol extract segment was by using nhexane for collecting $n$-hexane fraction in accordance to the different ratio of $n$-hexane and concentrated ethanol extract, corresponding to $1 / 1,1 / 2,1 / 3$, and $1 / 10(\mathrm{v} / \mathrm{v})$, named fraction L1 (1:1), fraction L1 (1:2), fraction L1 (1:3), and fraction L1 (1:10), respectively. After fraction by n-hexane, the under layer (UL) segment was continuously by using ethyl acetate for collecting ethyl acetate fraction in accordance to the different ethyl acetate-to-UL ratios, corresponding to $1 / 1,1 / 2,1 / 3$, and $1 / 10(\mathrm{v} / \mathrm{v})$, named fraction L3 (1:1), fraction L3 (1:2), fraction L3 (1:3), and fraction L3 (1:10), respectively.

$\mathrm{N}$-hexane fraction was continuously segmented by $96 \%$ ethanol for collecting ethanol fraction in accordance to the different ethanol-to-n-hexane ratios, corresponding to $1 / 1$, $1 / 2,1 / 3$, and $1 / 10(\mathrm{v} / \mathrm{v})$, named fraction L2 (1:1), fraction L2 (1:2), fraction L2 (1:3), and fraction L2 (1:10), respectively. All different fractions were analysed chlorophyll content, antioxidant activities, and tested $\mathrm{R}_{\mathrm{f}}$ on the thin layer chromatography.

\subsection{Chlorophyll purification}

Chlorophyll purification was by using the liquid-liquid method with different solvents, in turn, for example, nhexane, ethanol, and ethyl acetate. The concentrated ethanol extract segmented by using $n$-hexane for collecting $n$-hexane fraction that was concentrated and continuously segmented by using $96 \%$ ethanol according to the n-hexane/ethanol ratio of $1 / 1,2 / 1,3 / 1$, and $10 / 1(\mathrm{v} / \mathrm{v})$, respectively. Ethanol fraction was concentrated and segmented by using $n$-hexane according to the ethanol/n-hexane of $1 / 1,2 / 1,3 / 1$, and $10 / 1(\mathrm{v} / \mathrm{v})$, respectively. Ethyl acetate fraction was concentrated and segmented according to the ethyl acetate/ethanol ratio of $1 / 1,2 / 1,3 / 1$, and $10 / 1(\mathrm{v} / \mathrm{v})$ respectively. All fractions were concentrated, purified through the silica gel column and testing by using the thin layer chromatography.

\subsection{Quantification of chlorophyll content}

Chlorophyll (chl) content quantification was according to the method of Hiscox et al., (1979) 9. 96\% ethanol extract containing chlorophyll was measured the absorbance at the wavelength of $664.1 \mathrm{~nm}$ and $648.6 \mathrm{~nm}$, respectively, on the machine UV-Vis Varian Cary100 Bio EL 08023609 with a blank sample of $96 \%$ ethanol. Chlorophyll content calculation was according to the equation of Lichtenthaler $\mathrm{H}$. $\mathrm{K}$ [38] as follows:

Chlorophyll a content $(\mu \mathrm{g} \mathrm{chl} \mathrm{a/ml})=(13.36$ A664.1- 5.19 A648.6)

Chlorophyll b content $(\mu \mathrm{g} \mathrm{chl} \mathrm{b/ml})=\left(27.43 \mathrm{~A}_{648.6}-8.12\right.$ A664.1)

Where in: A648.6 and A664.1: the absorbance of the solution at the wavelength of $648.6 \mathrm{~nm}$ and $664.1 \mathrm{~nm}$.

\subsection{Determination of antioxidant activity}

\section{Mo $^{6+}$ metabolism activity}

Determination of $\mathrm{Mo}^{6+}$ metabolism activity was according to Aouicha et al. (2017), for example, $100 \mu \mathrm{l}$ of sample added to $900 \mu \mathrm{l}$ of distilled water and $03 \mathrm{ml}$ of solution A $\left(0.6 \mathrm{M} \mathrm{H}_{2} \mathrm{SO}_{4}\right.$, $28 \mathrm{mM}$ sodium phosphate, and $4 \mathrm{mM}$ ammonium Molybdate), in turn, vortexed and kept for 90 minutes at $95^{\circ} \mathrm{C}$. The absorbance measurement of compound was at the wavelength of $695 \mathrm{~nm}$ with the ascorbic acid standard 10 .

\section{$\mathrm{Fe}^{3+}$ metabolism activity}

Determination of $\mathrm{Fe}^{3+}$ metabolism activity was according to Vu Ngoc Boi et al. (2017). $500 \mu \mathrm{l}$ of sample added to $0.5 \mathrm{ml}$ of phosphate buffer ( $\mathrm{pH} \mathrm{7.2)} \mathrm{and} 0.2 \mathrm{ml}$ of $1 \% \mathrm{~K}_{3}\left[\mathrm{Fe}(\mathrm{CN})_{6}\right]$, in turn, and kept for 20 minutes at $50^{\circ} \mathrm{C}$. The compound added then to $500 \mu \mathrm{l}$ of $10 \% \mathrm{CCl}_{3} \mathrm{COOH}, 300 \mu \mathrm{l}$ of distilled water, and $80 \mu \mathrm{l}$ of $0.1 \% \mathrm{FeCl}_{3}$, in turn, for the absorbance measurement at $655 \mathrm{~nm}$ with the $\mathrm{FeSO}_{4}$ standard ${ }^{11}$.

\section{DPPH free radical scavenging activity}

DPPH free radical scavenging activity was determined according to Dang et al. (2016) and calculated in the equation 1, for example, kept the compounds (sample, blank, and control) under the dark condition for 30 minutes at the room temperature and the absorbance measurement at the wavelength of $550 \mathrm{~nm}$. The sample solution contained $200 \mu \mathrm{l}$, $400 \mu \mathrm{l}, 600 \mu \mathrm{l}, 800 \mu \mathrm{l}$, and $1000 \mu \mathrm{l}$ of extract and $3 \mathrm{ml}$ of DPPH $(25 \mathrm{mg} / \mathrm{l})$, in turn. The blank sample was similar to the sample solution but replacing DPPH by $3 \mathrm{ml}$ of absolute ethanol. The control sample forming was by replacing the extract in the blank sample by DPPH ${ }^{12}$.

$$
\mathrm{A} \%=\left[1-\left(\frac{\text { Asample }- \text { A blank }}{\text { A control }}\right)\right] \times 100 \%
$$

\subsection{Data analysis}

Each experiment was triplicated $(n=3)$, and the results were exhibited as the average of the triplication. Unvalue movement was by using the Duncan method. Statistics and ANOVA analysis were by using the software MS. Excel 2010.

\section{RESULTS AND DISCUSSION}

\section{1. n-Hexan fraction}

The extracting solvent affected chlorophyll content, total antioxidant activity, reducing power activity, and DPPH free radical scavenging $(\mathrm{p}<0.05)$, described by Aouicha et al. 10,13. Chlorophyll content and antioxidant activities decreased according to the increase of $n$-hexane ratio, and the increase of extracting times was a positive correlation to chlorophyll purification. Chlorophyll content, total antioxidant activity, reducing power activity, and DPPH free radical scavenging activity was the highest value corresponding to $1.218 \pm 0.015$ $\mu \mathrm{g}$ chl equivalent $/ \mathrm{ml}, 5.362 \pm 0.022 \mathrm{mg}$ ascorbic acid equivalent $/ \mathrm{ml}$ (Fig. 1), 13.142 $\pm 0.039 \quad \mathrm{mg} \quad \mathrm{FeSO}_{4}$ equivalent $/ \mathrm{ml}, 78.8 \pm 0.28(\%)$, respectively as the ethanol/nhexane ratio of $1 / 1$ (v/v) (Fig. 2). Other ethanol/n-hexane ratio caused the difference in chlorophyll content and antioxidant activities $\quad\left(\mathrm{F}=1957.19>\mathrm{F}_{\text {crit }}=4.06618\right)$. Chlorophyll content, total antioxidant activity, reducing power activity, and DPPH free radical scavenging activity of 
fraction L1 (1:1) corresponded to $1.94,3.41,3.45$, and 1.11 times, compared to fraction L1 (1:3), and decreased the following order: fraction L1 (1:1), fraction L1 (1:2), fraction L1 (1:3), and fraction L1 (1:10). The results in the current study were different in comparison to the previous studies, except for the impact of $n$-hexane on antioxidant chlorophyll content.

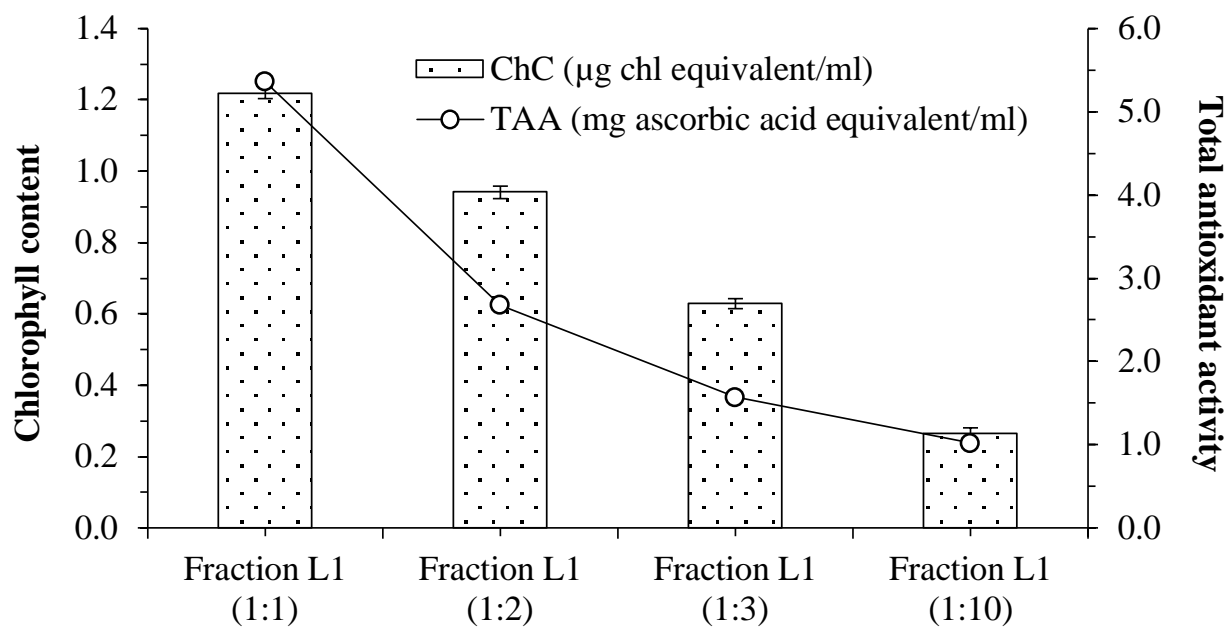

n-hexane fraction

Figure 1: Chlorophyll content and total antioxidant activity of $\mathbf{n}$-hexane fraction

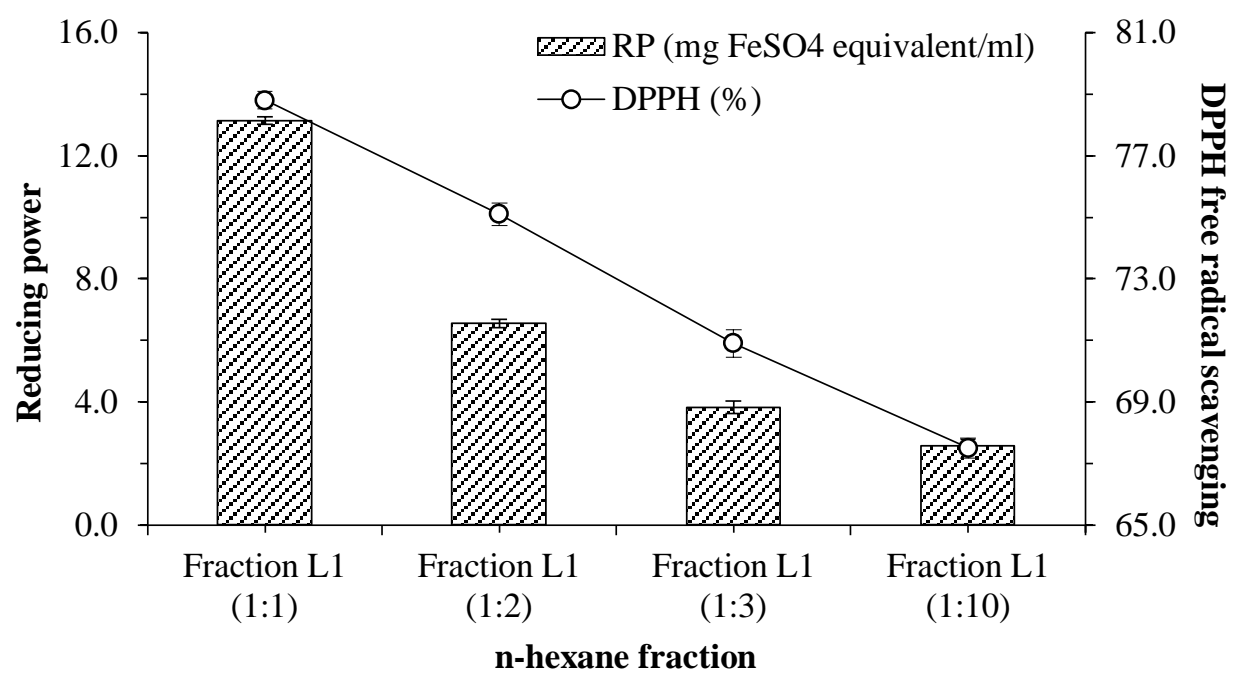

Figure 2: Reducing power activity and DPPH free radical scavenging activity of n-hexane fraction

\subsection{Ethanol fraction}

Chlorophyll content, total antioxidant activity, reducing power activity, DPPH free radical scavenging were different in other extracts $(\mathrm{p}<0.05)$, similar to the previous study 13,14 . The changing trend was similar to fraction n-hexane, chlorophyll content and antioxidant activities decreased when the ethanol ratio increased, and reverse. Chlorophyll content, total antioxidant activity, reducing power activity, and DPPH free radical scavenging activity got the highest value as the $n$-hexane/ethanol ratio of $1 / 1(\mathrm{v} / \mathrm{v})$, corresponding to $0.563 \pm 0.003 \mu \mathrm{g}$ chl equivalent $/ \mathrm{ml}$, $1.392 \pm 0.018 \mathrm{mg}$ ascorbic acid equivalent $/ \mathrm{ml}, 3.396 \pm 0,024$ $\mathrm{mg} \mathrm{FeSO}_{4} / \mathrm{ml}$, and 76.34 \pm 0.81 (\%), respectively. Chlorophyll content, total antioxidant activity, reducing power activity, and DPPH free radical scavenging activity got the lowest value as the $n$-hexane/ethanol ratio of $1 / 10(\mathrm{v} / \mathrm{v})$, corresponding to $0.118 \pm 0.005 \mu \mathrm{g} \mathrm{chl}$ equivalent $/ \mathrm{ml}$, $0.132 \pm 0.007 \mathrm{mg}$ ascorbic acid equivalent $/ \mathrm{ml}$ (Fig. 3), $0.338 \pm 0.018 \mathrm{mg} \mathrm{FeSO} / \mathrm{ml}$, and $66.53 \pm 0.71$ (\%) (Fig. 4), respectively (Fig. 4). Chlorophyll content and antioxidant activities increased in the following order: fraction L2 (1:10), fraction L2 (1:3), fraction L2 (1:2), and fraction L2 (1:1), respectively. Chlorophyll content, total antioxidant activity, reducing power activity, and DPPH free radical scavenging activity of fraction L2 (1:2) was 1.42, 1.61, 1.58, and 1.06 times, compared to fraction L1 (1:3), respectively. Chlorophyll content of ethanol fraction corresponded to $45.91 \%$ of n-hexane fraction. Antioxidant activities of ethanol fraction were in the range from $23.06 \%$ to $97.6 \%$ of $n$ hexane fraction. Therefore, antioxidants existed in $n$-hexane fraction and possessed antioxidant activity stronger than chlorophyll. Our previous studies showed polyphenol content account for a large proportion in dry weight of nhexane fraction, and polyphenol possessed antioxidant activity stronger than chlorophyll. The results exhibited chlorophyll that was extracted by using $96 \%$ ethanol and segmented by using n-hexane had an affinity to $96 \%$ ethanol less than n-hexane. These results in the current study were different, compared to the previous studies, except for chlorophyll possessing antioxidant activities. 


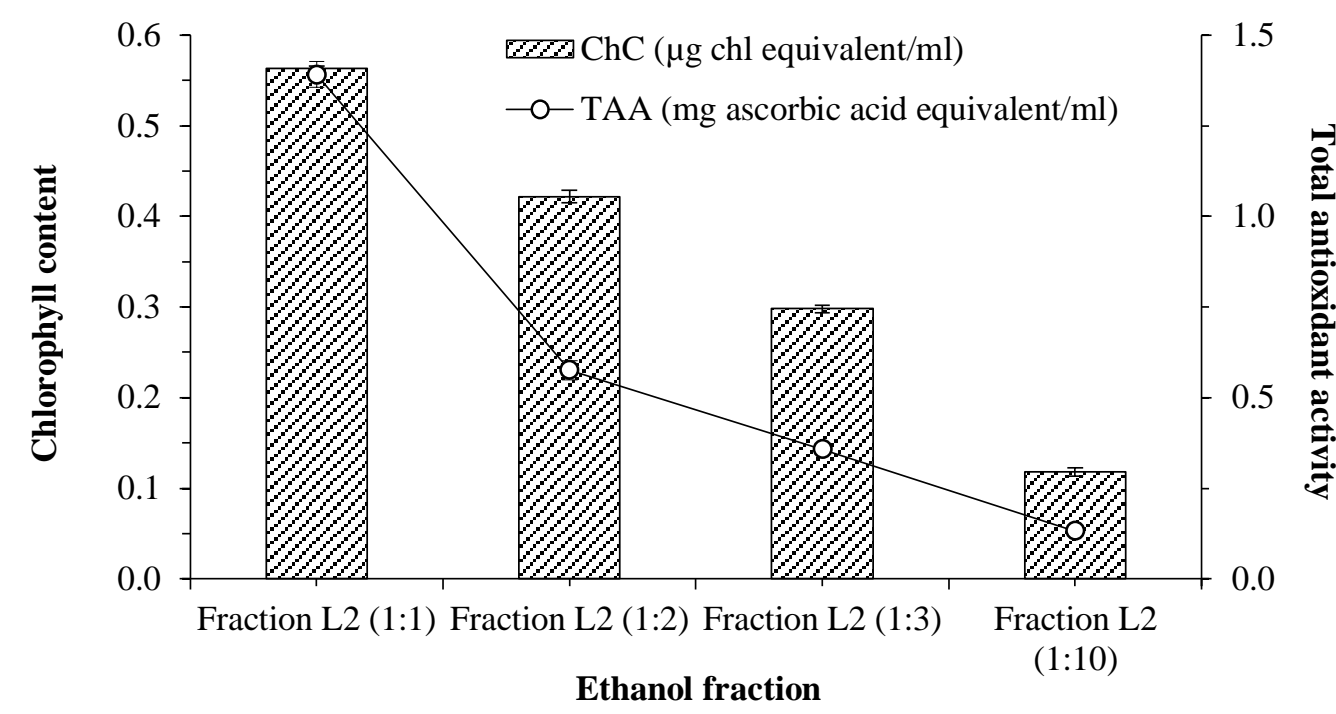

Figure 3: Chlorophyll content and total antioxidant activity of ethanol fraction

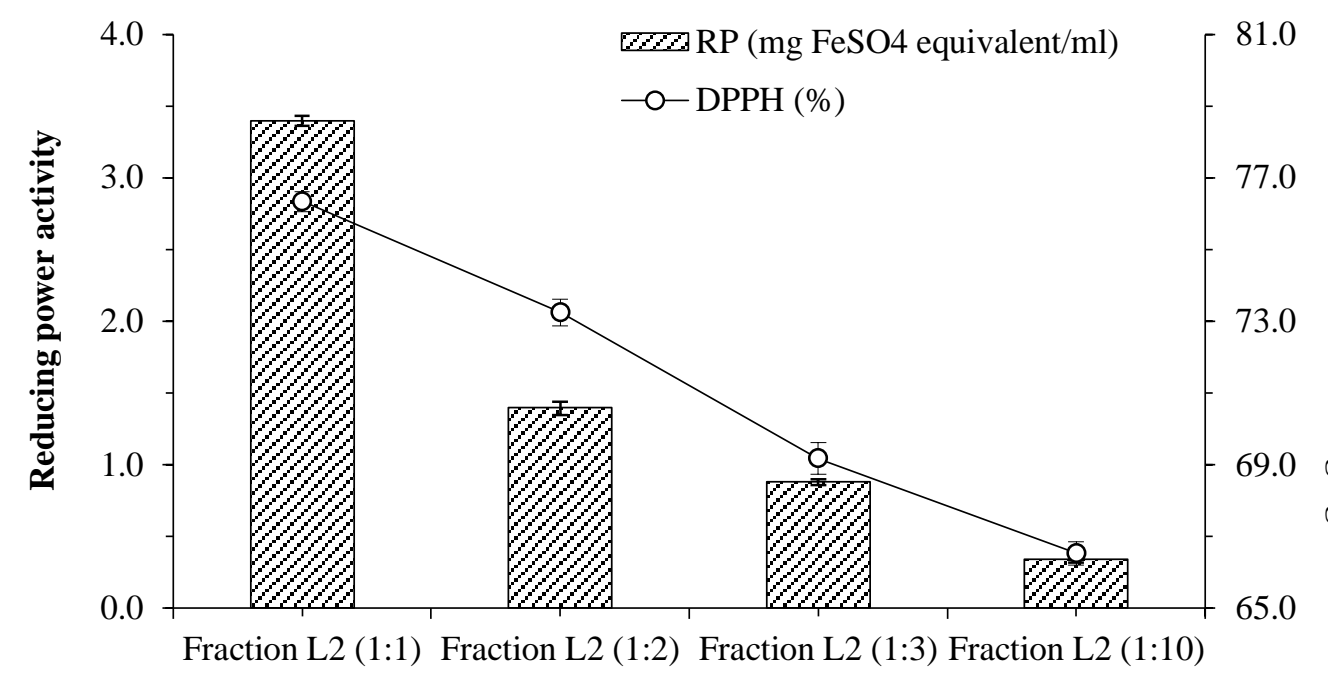



Ethanol fraction

Figure 4: Reducing power activity and DPPH free radical scavenging activity of n-hexane fraction

\subsection{Ethyl acetate fraction}

The results showed total antioxidant, reducing power activity, and DPPH free radical scavenging activity got the highest value in fraction L3 (1:1), in turn, $5.566 \pm 0.11 \mathrm{mg}$ ascorbic acid equivalent/ml (Fig. 5), 12.138 $\pm 0.12 \mathrm{mg}$ $\mathrm{FeSO}_{4} / \mathrm{ml}$, and $76.57 \pm 0.21$ (\%) (Fig. 6), respectively. Chlorophyll did not occur in ethyl acetate fraction that still contained other antioxidants, for example, polyphenol 15, and similarly in over, chlorophyll content in ethanol fraction was $45.92 \%$ of $n$-hexane fraction. Therefore, the binding affinity between solvent and chlorophyll decreased as follows: nhexane, ethanol, and ethyl acetate. Total antioxidant, reducing power activity, and DPPH free radical scavenging activity increased in the following order: fraction L3 (1:10), fraction L3 (1:3), fraction L3 (1:2), and fraction L3 (1:1), respectively. Chlorophyll content and antioxidant activities exhibited antioxidant activity depending on antioxidants purification degree, and it was suitable for the previous studies. Total antioxidant, reducing power activity, and DPPH free radical scavenging activity of fraction L3 (1:2) corresponded to $55.37 \%, 57.08 \%$, and $91.51 \%$, compared to fraction L3 (1:1), respectively.

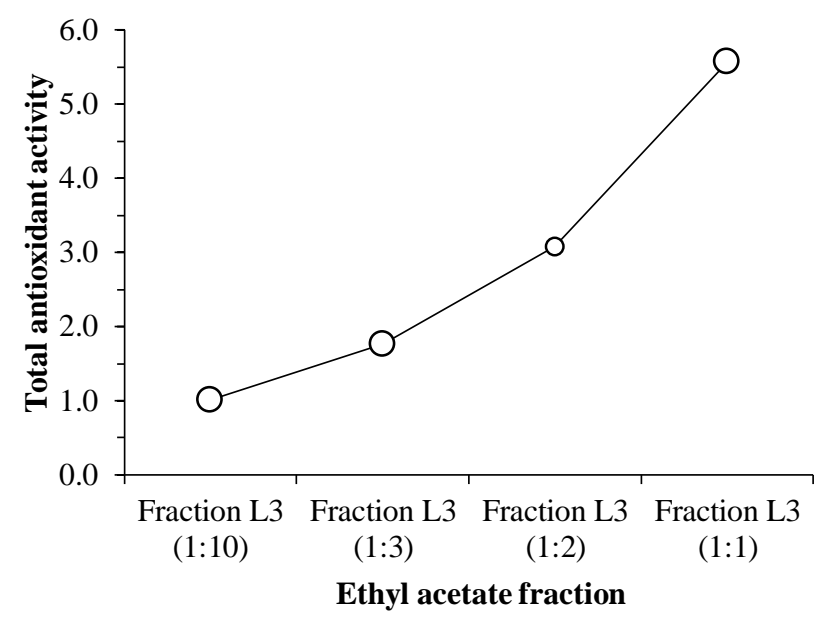

Fig 5 Total antioxidant activity of ethanol fraction 


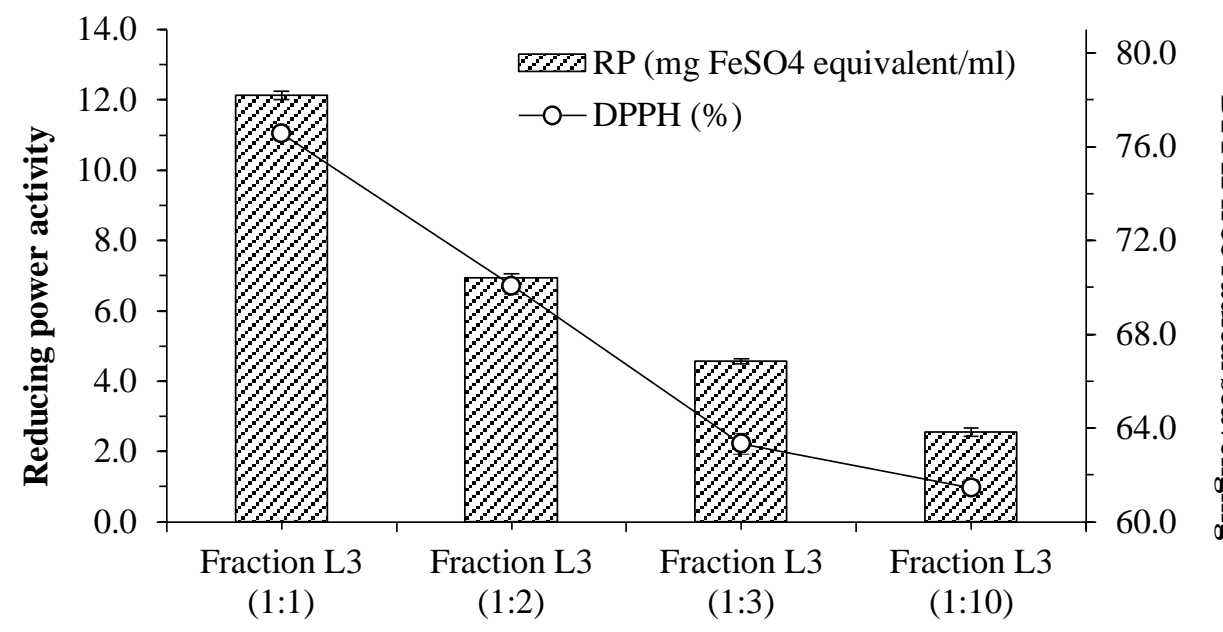

Ethyl acetate fraction

Fig 6 Reducing power activity and DPPH free radical scavenging activity of n-hexane fraction

\subsection{Antioxidant chlorophyll after the chromatography comlumn}

The results showed that the correlation between chlorophyll content and antioxidant activities was good after chlorophyll purification through the column $\left(\mathrm{R}^{2}>0.9\right)$. Chlorophyll content impacted antioxidant activities, and DPPH free radical scavenging activity was affected by chlorophyll content less than total antioxidant activity and reducing power activity. Chlorophyll content, total antioxidant activity, reducing power activity, and DPPH free radical scavenging activity got $0.217 \pm 0.002 \mu \mathrm{g}$ chl equivalent $/ \mathrm{ml}$, $0.628 \pm 0.013 \mathrm{mg}$ ascorbic acid equivalent $/ \mathrm{ml}, 1.928 \pm 0.019$ $\mathrm{mg} \mathrm{FeSO} 4 / \mathrm{ml}$, and 77.19 $\pm 0.58(\%)$, respectively. Purification degree of antioxidant chlorophyll increased according to the purification processing from the concentrated ethanol extract, n-hexane segment, ethanol segment before and after the chromatography column, corresponding to $56.31 \%$, $8.65 \%$, and $18.08 \%$, respectively. Chlorophyll extracting from maize leaves contained two kinds of chlorophyll a and $\mathrm{b}$, because two fractions of chlorophyll a and b occurred after the chromatography column.

\subsection{A correlation between chlorophyll content and antioxidant activity}

ANOVA analysis showed that chlorophyll content and antioxidant activities had a good correlation (significant level, $\alpha=0.05$ and $\mathrm{R}^{2}>0.9$ ). Chlorophyll content played a role in exhibiting antioxidant activities of different fractions. Chlorophyll content correlated total antioxidant activity, reducing power activity, and DPPH free radical scavenging activity well, corresponding to $0.924247,0.921008$, and 0.996145 , respectively. The correlation between total antioxidant activity and reducing power activity was good $\left(\mathrm{R}^{2}=0.999956\right)$ (Table 1), it was suitable for chlorophyll content and antioxidant activities correlation. DPPH free radical scavenging activity correlated to total antioxidant activity and reducing power activity of n-hexane fraction, corresponding to 0.947806 and 0.945343 , respectively.

Table 1: The correlation between chlorophyll content and antioxidant activities in hexane fraction

\begin{tabular}{|c|c|c|c|c|}
\hline & $\begin{array}{l}\text { Chlorophyll content } \\
\text { ( } \mu \text { g chl equivalent } / \mathrm{ml} \text { ) }\end{array}$ & $\begin{array}{l}\text { Total antioxidant activity } \\
\text { (mg ascorbic acid } \\
\text { equivalent/ } \mathrm{ml} \text { ) }\end{array}$ & $\begin{array}{l}\text { Reducing power activity } \\
\text { (mg FeSO } \\
\text { ml) equivalent/ }\end{array}$ & $\begin{array}{l}\text { DPPH free radical } \\
\text { scavenging } \\
\text { activity (\%) }\end{array}$ \\
\hline \multicolumn{5}{|l|}{ Chlorophyll content } \\
\hline ( $\mu \mathrm{g}$ chl equivalent/ml) & 1 & & & \\
\hline \multicolumn{5}{|l|}{ Total antioxidant activity } \\
\hline (mg ascorbic acid equivalent/ $\mathrm{ml}$ ) & 0.924247 & 1 & & \\
\hline \multicolumn{5}{|l|}{ Reducing power activity } \\
\hline (mg $\mathrm{FeSO}_{4}$ equivalent/ $\mathrm{ml}$ ) & 0.921008 & 0.999956 & 1 & \\
\hline $\begin{array}{l}\text { DPPH free radical scavenging } \\
\text { activity }(\%)\end{array}$ & 0.996145 & 0.947806 & 0.945343 & 1 \\
\hline
\end{tabular}

Chlorophyll content and antioxidant activities of ethanol fraction was also a good correlation (R2>0.9), for example, chlorophyll content and total antioxidant activity, reducing power activity, and DPPH free radical scavenging activity was $0.925727,0.923202$ and 0.988529 , respectively (Table 2). Total antioxidant activity correlated to reducing power activity and DPPH free radical scavenging activity was 0.999974 and 0.936049 . The correlation between reducing power activity and DPPH free radical scavenging activity was 0.933484 . The things exhibited chlorophyll had a metabolism ability of $\mathrm{Mo}^{6+}$ and $\mathrm{Fe}^{3+}$ better than free radical scavenging. 
Table 2: The correlation between chlorophyll content and antioxidant activities in ethanol fraction

\begin{tabular}{|c|c|c|c|c|}
\hline & $\begin{array}{l}\text { Chlorophyll content } \\
\text { ( } \mu \text { g chl equivalent } / \mathrm{ml} \text { ) }\end{array}$ & $\begin{array}{l}\text { Total antioxidant activity } \\
\text { (mg ascorbic acid } \\
\text { equivalent/ } \mathrm{ml} \text { ) }\end{array}$ & $\begin{array}{l}\text { Reducing power activity } \\
\left(\mathrm{mg} \mathrm{FeSO}_{4} \text { equivalent/ } \mathrm{ml}\right)\end{array}$ & $\begin{array}{l}\text { DPPH free radical } \\
\text { scavenging } \\
\text { activity (\%) }\end{array}$ \\
\hline Chlorophyll content & & & & \\
\hline ( $\mu \mathrm{g}$ chl equivalent/ml) & 1 & & & \\
\hline Total antioxidant activity & & & & \\
\hline $\begin{array}{l}\text { (mg ascorbic acid } \\
\text { equivalent/ } \mathrm{ml} \text { ) }\end{array}$ & 0.925727 & 1 & & \\
\hline Reducing power activity & & & & \\
\hline (mg $\mathrm{FeSO}_{4}$ equivalent/ $\mathrm{ml}$ ) & 0.923202 & 0.999974 & 1 & \\
\hline $\begin{array}{l}\text { DPPH free radical } \\
\text { scavenging activity (\%) }\end{array}$ & 0.988529 & 0.936049 & 0.933484 & 1 \\
\hline
\end{tabular}

The change law and the correlation of chlorophyll content and antioxidant activities were also exhibited through regression analysis and presented under the models of level 2 for both n-hexane and ethanol fraction (Table 3). The level-
2 model of chlorophyll content and antioxidant activities got the maximum peak with fraction L1 (1:1) and L2 (1:1). The things exhibited the extracting times increase led to the chlorophyll content decrease in the fraction.

Table 3: The correlation equation between chlorophyll content and antioxidant activities

\begin{tabular}{|l|l|l|}
\hline \multirow{2}{*}{ Antioxidant activity } & \multicolumn{2}{c|}{ Chlorophyll content } \\
\cline { 2 - 3 } & \multicolumn{1}{|c|}{ n-hexane fraction } & \multicolumn{1}{c|}{ Ethanol fraction } \\
\hline $\begin{array}{l}\text { Total antioxidant activity } \\
\text { (mg ascorbic acid equivalent/ } \mathrm{ml})\end{array}$ & $\mathrm{y}=6.1088 \mathrm{x}^{2}-4.6549 \mathrm{x}+1.8814$ & $\mathrm{y}=7.5059 \mathrm{x}^{2}-2.38 \mathrm{x}+0.3264$ \\
\hline $\begin{array}{l}\text { Reducing power activity } \\
(\mathrm{mg} \mathrm{FeSO}\end{array}$ equivalent/ ml) & $\mathrm{y}=15.28 \mathrm{x}^{2}-11.926 \mathrm{x}+4.79$ & $\mathrm{y}=18.483 \mathrm{x}^{2}-5.967 \mathrm{x}+0.8303$ \\
\hline DPPH free radical scavenging activity (\%) & $\mathrm{y}=3.4554 \mathrm{x}^{2}+6.8498 \mathrm{x}+65.403$ & $\mathrm{y}=16.171 \mathrm{x}^{2}+11.781 \mathrm{x}+64.78$ \\
\hline
\end{tabular}

\section{6. $\mathbf{R}_{\mathrm{f}}$ of Chlorophyll}

Chlorophyll test by using thin-layer chromatography showed that $\mathrm{R}_{\mathrm{f}}$ of chlorophyll varied from 0.46 to 0.96 for purification chlorophyll by using the liquid-liquid method. $\mathrm{R}_{\mathrm{f}}$ of chlorophyll was purified by the liquid-liquid method and running the column got the value of from 0.44 to 0.94 , respectively. The difference in $\mathrm{R}_{\mathrm{f}}$ of chlorophyll before and after purification by the column did not occur. $\mathrm{R}_{\mathrm{f}}$ of pigment groups was in the increasing order as follows: chlorophyll b, chlorophyll a, and carotenoid.

\begin{tabular}{|l|c|c|}
\hline & $\begin{array}{c}\text { After the liquid-liquid } \\
\text { purification }\end{array}$ & $\begin{array}{c}\text { After running the } \\
\text { column }\end{array}$ \\
\hline Các polyphenol (carotenoid): 1 stain (yellow - orange) & $\mathrm{R}_{\mathrm{f}}=6.7: 7=0.96$ & $\mathrm{R}_{\mathrm{f}}=6.6: 7=0.94$ \\
\hline Chlorophyl a: cyan, darker than chlorophyll b & $\mathrm{R}_{\mathrm{f}}=4.5: 7=0.64$ & $\mathrm{R}_{\mathrm{f}}=4.6: 7=0.66$ \\
\hline Chlorophyll b: green & $\mathrm{R}_{\mathrm{f}}=3.2: 7=0.46$ & $\mathrm{R}_{\mathrm{f}}=3.1: 7=0.44$ \\
\hline
\end{tabular}

\section{CONCLUSIONS}

Chlorophyll possessed antioxidant activities through a strong correlation between chlorophyll content and antioxidant activities. Chlorophyll exhibited the metabolism ability of iron better than free radical scavenging activity. Antioxidant chlorophyll from maize leaves was purified by using the liquid-liquid extraction method, in turn, ethanol, nhexane, and $96 \%$ ethanol, and run the column chromatography. Different fractions exhibited the highest value of chlorophyll content, total antioxidant activity, reducing power activity, and DPPH free radical scavenging activity when the extract-to-solvent ratio was $1 / 1(\mathrm{v} / \mathrm{v})$.
Chlorophyll content, total antioxidant activity, reducing power activity, and DPPH free radical scavenging activity of ethanol fraction before and after running the chromatography column corresponded to $0.563 \pm 0.003 \mu \mathrm{g}$ chl equivalent $/ \mathrm{ml}, 1.392 \pm 0.018 \mathrm{mg}$ ascorbic acid equivalent $/ \mathrm{ml}, 3.396 \pm 0.024 \mathrm{mg} \mathrm{FeSO} / / \mathrm{ml}$, and $76.34 \pm 0.81$ (\%), and $0.217 \pm 0.002 \mu \mathrm{g}$ chl equivalent $/ \mathrm{ml}, 0.628 \pm 0.013 \mathrm{mg}$ ascorbic acid equivalent/ml, $1.928 \pm 0.019 \mathrm{mg} \mathrm{FeSO} / 4 \mathrm{ml}$, and $77.19 \pm 0.58(\%)$, respectively. Purification degree of antioxidant chlorophyll increased according to the purification processing and corresponded to $10.23 \%$, $66.54 \%, \quad 75.19 \%$, and $93.27 \%$, corresponding to concentrated ethanol extract, n-hexane segment, ethanol 
segment before and after the chromatography column. Antioxidant chlorophyll has potential in application in functional food and pharmaceutical.

\section{ACKNOWLEDGMENT:}

Thankful for the funding of Vietnam Academy of Science and Technology and the project "UDSPTM.04/20-21" of Department of Application \& Development of Technology.

\section{CONFLICT OF INTEREST}

No conflict of interest.

\section{REFERENCES}

1. Janet BVD. Nobel Lectures in chemistry 1901-1921. J Chem Educ. 1967; 1(44):A472.

2. Natsuki H. Sachi SK. Nobel prizes for research in plant science: Past, present and future. Reviews in Agricultural Science 2017; 5:83-99.

3. Luxsika N. Sakamon D. Naphaporn C. Effects of pretreatment and drying methods on molecular structure, functional properties and thermal stability of fibre powder exhibiting colour from Centella asiatica L. Int J Food Sci. 2016; 51(3):753764.

4. Aris H. Su L. Ronald H. Michael KD. Chlorophyll extraction from microalgae: A review on the process engineering aspects. Int J Chem Eng. 2010; 1-11.

5. Ursula ML-M. Rosa MCB. Patricia S. Antioxidant activity of chlorophylls and their derivatives. Food Res Int. 2005; 38:885891.

6. Levent İA. Chlorophyll: Structural properties, health benefits and its occurrence in virgin olive oils. Akademik Gıda. 2011; $9(2): 26-32$.
7. Benjamin GMD. Chlorophyll-Its therapeutic place in acute and suppurative disease: Preliminary report of clinical use and rationale. The American Journal of Surgery. 1940; 49(1):49-55.

8. Kateřina V. Ivana M. Jana J. Aleš D. Iva S. Jaroslav Z. Iva N. Jan R. Tomáš V. Roman S. Lucie M. Libor V. Chlorophyll-mediated changes in the redox status of pancreatic cancer cells are associated with its anticancer effects. Oxid Med Cell Longev. 2018; 1-11.

9. Hiscox J. Tsraelstam G. A method for the extraction of chlorophyll from leaf tissue without maceration. Can J Bot. 1979; 57:1332-1334.

10. Aouicha E. Hanane EH. Hassan F. Anouar A. Brahim EB. Mohammed L. Phytochemical screening and evaluation of antioxidant and antibacterial activities of seeds and pods extracts of Calycotome villosa subsp. Intermedia. Journal of Applied Pharmaceutical Science. 2017; 7(04): 192-198.

11. Vu NB. Dang XC. Phan TKV. Effects of extraction conditions over the phlorotannin content and antioxidant activity of extract from brown algae Sargassum serratum (Nguyen Huu Dai 2004). Free Radicals and Antioxidants. 2017; 7(1):115122.

12. Dang XC. Vu NB. Tran TTV. Le NH. Effect of storage time on phlorotannin content and antioxidant activity of six Sargassum species from Nhatrang Bay, Vietnam. J Appl Phycol. 2016; 28(1):567-572.

13. Pierre N. Edith NF. Carl MFM. Effects of age and extraction solvent on phytochemical content and antioxidant activity of fresh Moringa oleifera L. leaves. Food Sci Nutr. 2018; 1-11.

14. Ursula ML-M. Rosa MB. Patricia S. Antioxidant activity of chlorophylls and their derivatives. Food Res Int. 2005; 38:885891.

15. Dang XC. Nguyen XH. Dinh HD. Le TMT. Nguyen VT. Hoang TH. Dang TTT. Dang XC, Tannins: Extraction from plants. In: Alfredo A, editor. Tannins - Structural properties, biological properties and current knowledge. Intech0pen. 2019; 1-20. 